\title{
Effect of pre-test rest duration on toe and ankle systolic blood pressure measurements
}

\author{
Sean Sadler ${ }^{*}$, Vivienne Chuter, Fiona Hawke \\ From Australasian Podiatry Council Conference 2013 \\ Sydney, Australia. 2-5 June 2013
}

\section{Background}

Measurement of toe and ankle blood pressure is used to evaluate the peripheral arterial status of patients, yet the pre-test rest period is inconsistent in published studies and among practitioners, and could affect results. The aim of this systematic review was to evaluate all research that has investigated the effect of different periods of pre-test rest on toe and ankle systolic blood pressure.

\section{Methods}

MEDLINE (from 1946), EMBASE (from 1947), CINAHL (from 1937), and Cochrane Central Register of Controlled Trials (CENTRAL) (from 1800) were searched up to April 2012. No language or publication restrictions were applied. Eighty-eight content experts and researchers in the field were contacted by email to assist in the identification of published, unpublished, and ongoing studies. Studies evaluating the effect of two or more pretest rest durations on toe or ankle systolic blood pressure were eligible for inclusion. No restrictions were placed on participant characteristics or the method of blood pressure measurement. Outcomes included toe or ankle systolic blood pressure and adverse effects. Abstracts were independently assessed by two reviewers for potential inclusion.

\section{Results}

1658 abstracts were identified by electronic searching. Thirty three of the 88 content experts and researchers in the field replied, identifying five potentially relevant studies. No studies were eligible for inclusion.

* Correspondence: Sean.Sadler@newcastle.edu.au

Podiatry Department, The University of Newcastle, Ourimbah, NSW, 2258, Australia
doi:10.1186/1757-1146-6-S1-P13

Cite this article as: Sadler et al: Effect of pre-test rest duration on toe and ankle systolic blood pressure measurements. Journal of Foot and Ankle Research 2013 6(Suppl 1):P13.

Submit your next manuscript to BioMed Central and take full advantage of:

- Convenient online submission

- Thorough peer review

- No space constraints or color figure charges

- Immediate publication on acceptance

- Inclusion in PubMed, CAS, Scopus and Google Scholar

- Research which is freely available for redistribution 